\title{
The effect of life-cycle stage through cash flow approach on dividend policy of manufacturing companies
}

\author{
Ibnu Hasan Azmi ${ }^{a^{*}}$ and Eka Bertuah ${ }^{\mathrm{b}}$
}

${ }^{a}$ Magister Student, Faculty of Economics and Business, Esa Unggul University, Indonesia ${ }^{b}$ Lecturer of Faculty of Economics and Business, Esa Unggul University, Indonesia

\section{A B S T R A C T}

\begin{abstract}
The present study aims to determine the effect of a company's life-cycle stage, profitability, institutional ownership, and liquidity on dividend policy as well as the effect of dividend policy on firm value. Data were run through logistic regression analysis and ANNOVA test with total sample data of 31 companies in the consumer goods industry sector listed on the Indonesia Stock Exchange over the period 2014-2018. With control variables consisting of asset growth, corporate debt, and investment cash flow, it is determined that the growth and maturity life-cycle stages as well as return on assets of a company had positive and significant effects on dividend policy. Companies at growth and maturity stages provided dividends since they attempted to show to shareholders that the company was under good financial and profitable conditions. Corporate debt also had a significant effect on dividend policy where the relationship was inversely proportional, meaning that companies with large debt ratios tend not to provide dividends. Other results show that there was a significant difference between dividend policy and firm value. Companies that provide dividends tend to be overvalued since it leads to increase in the confidence of shareholders to invest.
\end{abstract}

(C) 2021 by the authors; licensee Growing Science, Canada

\section{Introduction}

Dividend policies are often considered as part of spending decisions, especially that of internal expenditure. The reasons as to why companies pay dividends can be an alternative explanation of the free cash flow hypothesis which considers dividends as a way to reduce agent costs from free cash flow (Jensen, 1986). The problem is that the existence of a large free cash flow within a company is damaging to the company's value. The amount of free cash flow available can be allocated to shareholders in the form of dividends to reduce agency conflicts between shareholders and managers. This dividend distribution serves to reduce the available funds and encourage companies to get new funds from the capital market (Amar, Salah \& Jarboui, 2017). Based on life-cycle theory, large and mature companies tend to have good cash flow. They tend to pay more dividends than small and medium-sized companies because of the size of the company (Fama \& French, 2001). Several literatures approach the life cycle stage of a company based on age and size of the company such as the views of Bulan, Subramanian \& Tanlu (2011), Bradshaw et al. (2012), Bhattacharya, Black, Christensen \& Mergenthaler (2004), and Desai et al. (2006). Other studies use a company's age as an independent variable to determine its effect on dividend policy, but the results show there is no influence of age on dividend policy as conveyed by Kilinçarslan (2018), Sukkaew (2015) and Vaidean \& Moza (2010). According to Dickinson (2011), the stages of a company's life cycle differ are independent of the age of the company in which companies of the same age may have different levels of achievement. Each company is a portfolio of several potential products at different stages of the product life cycle. Dickinson (2011) proposed a company's life cycle pattern based on a cash flow approach that categorizes the life cycle stage of a company by looking at the cash flow from operations, investments, and financing. Classification stages * Corresponding author.

E-mail address: ibnu.hasanazmi@gmail.com (I. H. Azmi) 
of a company's life cycle play a role in understanding the value of that company and in predicting the distribution of dividends. Dividend payments begin with the company's profitability (Al-Malkawi, 2007). Profitable companies are better able to pay dividends and generate internal funds (retained earnings) to finance investments. Dividend payments are considered as a company liquidation. According to Brahmaiah et al. (2018), companies that have high liquidity will pay higher dividends due to excessive amounts of cash. In developing countries, ownership structure is dominantly owned by institutional investors that hold the company's management, thus it holds an important position that influences decision making (Mili, Sahut \& Teulon, 2017). Budiarso (2019) has previously conducted a study with dividend policy as a dependent variable, return on assets (profitability) as an independent variable along with debt to assets (leverage) and asset growth as control variables. Other research conducted by Alzoubi (2019) uses the cash ratio dependent variable and the independent variable of the company's cycle stage. Mili et al. (2017) in his study used the variable institutional ownership to determine its effect on dividend policy.

The present study, however, does not use the age of a company as an approach in the life-cycle stage of a company but instead uses the approach of cash flow. This study also integrates the company's life cycle as an independent variable. The effect of the company's life-cycle stage on the decision to provide dividends has not been much investigated in previous research. Therefore, the aim of this research is to understand how companies make dividend policies according to the stages in their life cycle. In addition, due to the incomplete fulfillment of capital markets, a claim made by Miller and Modigliani (1961) that there is no relationship between dividends and stock prices cannot be maintained. Therefore, it is interesting to examine whether there is an influence between dividend policy on firm value.

\section{Literature Review}

\subsection{Bird-in-Hand Theory}

This theory emphasizes that the equity or profit of a company will decrease if the dividend payout ratio is increased since investors are likely to be less confident about the capital gains resulting from retained earnings in contrary to when investors receive dividends. Investors value the income expected from dividends far more than the income expected from capital gains. Investors have the consider that dividends have less risk, thus prefering to receive ready money than to expect future capital gains that are uncertain. The effect of dividend policy on firm value has previously been evaluated by Elim (2019), Abor \& Bokpin (2010) and Salih (2010), in which dividend payments can increase the value a company.

\subsection{Agency/Free Cash Flow Theory}

This theory focuses on conflicts of interest between management and shareholders. The main task of management is to increase shareholders wealth and manage the business appropriately. Agency problems arise when there is excess cash flow in a company that should be used for profitable projects but is instead used for the personal benefit of the company and the shareholders. Rozeff (1982) suggested reducing agency problems through provision of dividends from company profits. According to Shubiri, Taleb \& Zoued (2012) and Elston et al. ( 2011) there is a relationship between institutional ownership and dividend policy. Moreover, Kighir et al. (2015) found that a company's cash flow affects dividend policy.

\subsection{Life-Cycle Theory}

Corporate decisions are affected by the different stages of their life cycle. In the life-cycle model, optimal dividend policy is applied when a company's trade costs are stable and there are allocations of costs to anticipate agency costs of free cash flow. When companies are in its early stages, they would experience growth and have relatively small obligations for internal financing in which they tend to avoid dividend payments. At a mature stage, companies pay dividends when they generate sufficient internal funds because investment opportunities are declining. Distributing dividends and repurchasing shares become important at this stage in the life-cycle phase because companies will face substantial problems regarding free cash flow when cash accumulates (Hauser \& Thornton, 2017). Bulan et al. (2011), using a corporate age approach, determined the stage of a company's life-cycle and found that mature companies tend to pay dividends. Dickinson (2011) used different factors to evaluate the life-cycle stage of the company composing of operational cash flow, investment cash flow and financial cash flow.

\subsection{Hypothesis Formulation}

\subsubsection{Relationship between Profitability and Dividend Policy}

According to Al-Malkawi (2007), the decision to pay dividends starts with profit. Therefore, it is logical to consider profit as a very important factor in making dividend decisions. Khalid \& Rehman (2015), Al-Najjar \& Kilincarslan (2017) and Budiarso (2019) found Return On Assets to have an influence on dividend policy. Based on the description above, the first hypothesis is as follows:

$\mathrm{H}_{1}$ : A profitable company will tend to provide dividends. 


\subsubsection{Relationship between Corporate Life Cycle Stage and Dividend Policy}

Based on the company's life cycle theory, large and mature companies tend to have large cash flow which implies fewer longterm investment stocks, paying a greater dividend than newly emerging companies (Fama \& French, 2001). According to Alzoubi (2019), there is a relationship between the maturity stage of companies and dividends and that newly emerging and growing companies generally do not provide dividends. Hence, the second set of hypotheses proposed are:

$\mathrm{H}_{2 \mathrm{a}}$ : Companies that are at a new stage (Introduction) tend not to provide dividends.

$\mathrm{H}_{2 \mathrm{~b}}$ : Companies that are at a growth stage tend not to provide dividends.

$\mathrm{H}_{2 \mathrm{c}}$ : Companies that are at the mature stage tend to provide dividends.

\subsubsection{Relationship between Institutional Ownership and Dividend Policy}

An entity with institutional ownership usually has owns a large portion of a company and tends to invest for a long time. The entity also has the power to monitor and control management in making financial decisions (Elim, 2019). According to Shubiri et al. (2012) and Hofler et al. (2011), there is a relationship between institutional ownership and dividend policy. Thus, this study proposes a third hypothesis:

$\mathrm{H}_{3}$ : Companies with dominant institutional ownership tend to provide dividends.

\subsubsection{Relationship between Liquidity and Dividend Policy}

Liquidity is a dominant factor that plays role in the decision to pay dividends. A company might make a profit but lack the cash to declare dividends. Therefore, liquidity is needed to anticipate the payment of high dividend money (Brahmaiah et al., 2018). Al-Kayed (2017) and El-Nader (2018) claim that there is a relationship between company liquidity and dividend payments. Thus, this research proposes the fourth hypothesis as follows:

$\mathrm{H}_{4}$ : Liquid companies tend to provide dividends.

\subsubsection{Control Variables}

To confirm the effect of the company's life-cycle stage, this study uses corporate debt, asset growth and investment cash flow as control variables. Companies at an early and growing stages have positive financial cash flow due to the high debt of those companies in the efforts to get funds from creditors. Faccio, Lang \& Young (2001) and Al-Rahahleh (2017) find that large debts reduce dividend payments to investors. On the other hand, companies tend to hold profits when growth is high. The occurence of fast company growth implies that funds are better needed for business expansion. According to Ali, Gohar \& Meharzi (2017), companies will start paying dividends when growth is as expected.

\subsubsection{Relationship between Dividend Policy and Firm Value}

Agency problems occur when management denies its obligation to maximize the value of the company. Rozeff (1982) suggested reducing agency problems through dividend payments out of company profits. By doing so, management can avoid investment in projects that are not profitable. According to Abor \& Bokpin (2010) and Salih (2010), dividend policy has an effect on firm value. Based on the description above, the fifth hypothesis is proposed as follows:

$\mathrm{H}_{5}$ : Companies that provide dividends will increase the value of the company (the value of the company will be overvalued).

Based on the formulation of the above hypotheses, the following research framework of thought is presented:

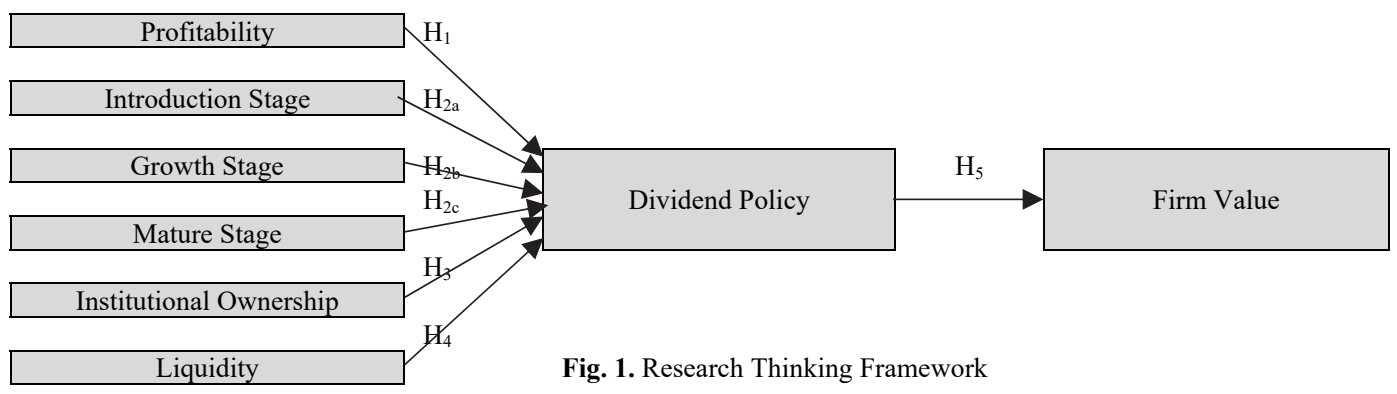

\section{Methodology}

The research population consist of publicly known manufacturing sector companies that provide consumer goods listed on the Indonesia Stock Exchange. The technique of data sampling used was purposive sampling where as many as 31 companies were sampled in this study. These companies were chosen for their comprehensive data on financial statements as well as their fulfilment of the research criteria of consecutively paying or not paying cash dividends during 2014-2018 period. Method of data analysis used in this study is the logistic regression analysis intended to study dividend policy as well as one sample chi- 
square difference test to assess firm value. Logistic regression analysis is used to analyze discrete dependent variables (Hosmer $\&$ Lemeshow, 2000). This research has the following research model.

$$
D I V_{i t}=\alpha+\beta_{1} R O A_{i t}+\beta_{2} I N_{i t}+\beta_{3} G R_{i t}+\beta_{4} M T_{i t}+\beta_{5} K I_{i t}+\beta_{6} C R_{i t}+\beta_{7} A G_{i t}+\beta_{8} D A R_{i t}+\beta_{9} A I_{i t}+\varepsilon_{i t}
$$

where:

$\begin{array}{llllll}\alpha & =\text { Constant } & \text { CR } & \text { Liquidity } & \text { KI } & \text { Institutional Ownership } \\ \beta & =\text { Regression Coefficient } & \text { AG } & =\text { Asset Growth } & \text { AI } & =\text { Investment Cash Flow } \\ \text { DIV } & =\text { Cash Dividend Policy } & \text { DAR } & =\text { Corporate Debt } & \mathrm{i} & =\mathrm{i} \text { The company } \\ \text { ROA } & =\text { Profitability } & \text { GR } & =\text { Growth Stage } & \mathrm{t} & =\text { t Period } \\ \mathrm{IN} & =\text { Introduction Stage } & \text { MT } & =\text { Mature Stage } & \varepsilon & =\text { Error }\end{array}$

Table 1

Measurement of Research Variables

\begin{tabular}{|c|c|c|c|c|}
\hline Variable & Definition of operational variables & Measurement Method & Scale & Previous Research \\
\hline Firm Value & $\begin{array}{l}\text { Share price divided by book value. } \\
\text { If }>1 \text { it is Overvalued, if }<1 \text { it is } \\
\text { Undervalued }\end{array}$ & $\begin{array}{l}\mathrm{FV}=\text { Overvalued }(1) \\
\mathrm{FV}=\text { Undervalued }(0)\end{array}$ & nominal & Husna \& Satria (2019) \\
\hline Dividend & $\begin{array}{l}\text { Companies that pay dividends and do } \\
\text { not pay dividends }\end{array}$ & $\begin{array}{l}\text { DIV }=\text { Pays dividends }(1) \\
\text { DIV }=\text { Does not pay dividends }(0)\end{array}$ & nominal & Al-Rahahleh (2017) \\
\hline Profitability & $\begin{array}{l}\text { Net profit after tax divided by total } \\
\text { assets }\end{array}$ & $\mathrm{ROA}=\frac{\text { Net Profit }}{\text { Total Assets }} \times 100$ & ratio & $\begin{array}{l}\text { Rahmawati, Moeljadi, Djumahir } \\
\text { \& Sumiati (2018) and Utami \& } \\
\text { Gumanti (2019) }\end{array}$ \\
\hline Introduction Stage & $\begin{array}{l}\text { Negative operating cash flow, } \\
\text { negative investment cash flow and } \\
\text { positive financial cash flow. }\end{array}$ & $\begin{array}{l}\text { IN = Negative operating cash flow, negative investment } \\
\text { cash flow and positive financial cash flow (1). } \\
\text { IN = Other than category } 1(0)\end{array}$ & nominal & Alzoubi (2019) \\
\hline Growth Stage & $\begin{array}{l}\text { Positive operating cash flow, } \\
\text { negative investment cash flow and } \\
\text { positive financial cash flow. }\end{array}$ & $\begin{array}{l}\text { GR = Positive operating cash flow, negative investment } \\
\text { cash flow and positive financial cash flow (1) } \\
\text { GR = Other than category } 1(0)\end{array}$ & nominal & Alzoubi (2019) \\
\hline Variable & Definition of operational variables & Measurement Method & Scale & Previous Research \\
\hline Mature Stage & $\begin{array}{l}\text { Positive operating cash flow, } \\
\text { negative investment cash flow and } \\
\text { negative financial cash flow. }\end{array}$ & $\begin{array}{l}\text { MT = Positive operating cash flow, negative investment } \\
\text { cash flow and negative financial cash flow (1) } \\
\text { MT = Other than category } 1(0)\end{array}$ & nominal & Alzoubi (2019) \\
\hline Debt & Total debt divided by total assets & $\mathrm{DAR}=\frac{\text { Total debt }}{\text { Total Assets }}$ & ratio & $\begin{array}{l}\text { Rój (2019), Bertuah \& Ghani } \\
\text { (2018) }\end{array}$ \\
\hline Liquidity & $\begin{array}{l}\text { Current assets divided by current } \\
\text { debt }\end{array}$ & $\mathrm{CR}=\frac{\text { Current Assets }}{\text { Current Debt }} \times 100$ & ratio & Hakeem \& Bambale (2016) \\
\hline $\begin{array}{l}\text { Institutional } \\
\text { Ownership }\end{array}$ & $\begin{array}{l}\text { Institutional ownership divided by } \\
\text { total shares outstanding }\end{array}$ & $\mathrm{KI}=\frac{\text { Institutional Ownership }}{\text { Total shares outstanding }} \times 100$ & ratio & $\begin{array}{l}\text { Shubiri et al. (2012) and Hofler, } \\
\text { Elston \& Lee (2011) }\end{array}$ \\
\hline Asset Growth & $\begin{array}{l}\text { Difference in total assets at } t \text { year and } \\
t-1 \text { year divided by total assets of } t-1 \\
\text { year }\end{array}$ & $\mathrm{AG}=\frac{\text { Total }_{\text {Assets }}-\text { Total Assets }_{t-1}}{\text { Total Assets }_{t-1}} \times 100$ & ratio & Budiarso (2019) \\
\hline $\begin{array}{l}\text { Investment Cash } \\
\text { Flow }\end{array}$ & $\begin{array}{l}\text { Investment cash flow divided by total } \\
\text { assets }\end{array}$ & $\mathrm{AI}=\frac{\text { Investment Cash Flow }}{\text { Total assets }}$ & ratio & $\begin{array}{l}\text { Brook, Charlton \& Hendershott } \\
\text { (1998) }\end{array}$ \\
\hline
\end{tabular}

\section{Results}

There are 19 companies that actively pay dividends and 12 companies that do not pay dividends. Descriptive data for companies that pay and do not pay dividends are presented in Table 2. In this table, descriptive data comparisons among the variables observed in this study between companies that pay dividends and companies that do not pay dividends are presented. Significant differences are seen in the Return on Assets (ROA) variable and the mature stage company (MT) variable. The results of the logistic regression analysis of the dividend policy dependent variable can be seen in Table 3 below.

Table 2

Descriptive Data for Companies that Pay and Do Not Pay Dividends

\begin{tabular}{|c|c|c|c|c|c|c|c|c|}
\hline \multirow{2}{*}{ Variable } & \multicolumn{4}{|c|}{ Pay Dividend } & \multicolumn{4}{|c|}{ Do Not Pay Dividend } \\
\hline & Min & $\operatorname{Max}$ & Mean & Mode & Min & Max & Mean & Mode \\
\hline FV & 0 & 1 & & 1 & 0 & 1 & & 1 \\
\hline ROA & -6.87 & 92.10 & 15.40 & & -20.76 & 13.72 & 0.41 & \\
\hline IN & 0 & 1 & & 0 & 0 & 1 & & 0 \\
\hline GR & 0 & 1 & & 0 & 0 & 1 & & 0 \\
\hline MT & 0 & 1 & & 1 & 0 & 1 & & 0 \\
\hline $\mathrm{KI}$ & 49.90 & 99.78 & 87.92 & & 24.14 & 98.49 & 79.17 & \\
\hline CR & 0.51 & 10.25 & 3.03 & & 0.28 & 7.90 & 2.09 & \\
\hline $\mathrm{AG}$ & -10.52 & 58.91 & 12.44 & & -22.83 & 621.88 & 19.41 & \\
\hline DAR & 0.07 & 0.75 & 0.38 & & 0.04 & 1.25 & 0.51 & \\
\hline AI & -0.21 & 1.14 & -0.05 & & -0.25 & 0.005 & -0.06 & \\
\hline
\end{tabular}

Note: SPSS software data processing. 
Table 3

Logistic Regression for Dividend Policy

\begin{tabular}{|c|c|c|c|c|}
\hline \multirow[b]{2}{*}{ Independent variable } & \multicolumn{4}{|c|}{ Model } \\
\hline & Without control variable & 1 control variable & 2 control variables & 3 control variables \\
\hline Intercept & -4.454 & -4.456 & -4.419 & -2.358 \\
\hline ROA & $0.236 * *$ & $0.236 * *$ & $0.245^{* *}$ & $0.241 * *$ \\
\hline IN & 1.627 & 1.625 & 1.812 & 1.762 \\
\hline GR & $2.671 * *$ & $2.670 * *$ & $2.928 * *$ & $3.020 * *$ \\
\hline MT & $2.982 * *$ & $2.982 * *$ & $3.125 * *$ & $3.064 * *$ \\
\hline $\mathrm{KI}$ & 0.011 & 0.011 & 0.01 & 0.009 \\
\hline CR & 0.002 & 0.002 & -0.015 & -0.185 \\
\hline $\mathrm{AG}$ & & 0.001 & 0.001 & 0.003 \\
\hline AI & & & 2.435 & 2.821 \\
\hline DAR & & & & $-3.476 * *$ \\
\hline Pseudo R-Square & 0.613 & 0.613 & 0.614 & 0.633 \\
\hline
\end{tabular}

Note: SPSS software data processing. $* * 5 \%$ significance.

From Table 3 above, the results of the logistic regression analysis presents a regression equation for the dependent and independent variables along with the control variables as follows:

$$
D I V_{i t}=-2.358+0.241 R O A_{i t}+3.020 G R_{i t}+3.064 M T_{i t}-3.476 D A R_{i t}+\varepsilon_{i t}
$$

Based on Table 3 above, estimated variables of Return on Assets (ROA) with a coefficient value of 0.241 , growth stage company (GR) with a coefficient value of 3.020 and mature stage company (MT) with a coefficient value of 3.064 are obtained, in which all three have a positive and significant influence towards dividend policy with probability of $<0.05$. A negative and significant effect is seen for the variables Corporate Debt (DAR), with a coefficient of $-3,476$. The data also exhibit increase in the values of Pseudo R-Squared after inputting the control variables with values of $61.3 \%$ to $63.3 \%$. This shows that $63.3 \%$ of the dividend policy is influenced by the independent variables. The results of the one sample chi-square difference test between dividend policy variables and firm value can be seen in Table 4 below.

\section{Table 4}

One Sample Chi-Square One Test Difference Between Dividend Policy and Firm Value Variables

\begin{tabular}{lcc}
\multicolumn{1}{c}{ Dividend Policy } & Statistical Test & Value \\
Pay Dividend & Chi-Square & 62.411 \\
Do Not Pay Dividend & Chi-Square & $0.000 * * *$ \\
\hline Note: SPSS software data processing $* * * 1 \%$ significance. & 0.100 \\
\hline
\end{tabular}

Note: SPSS software data processing. *** $1 \%$ significance.

Based on Table 4 above, the one sample chi-square difference test results obtained a value of 62,411 for companies that provide dividends with a significance of $0,000<0.05$, meaning that there is legitimate difference in the values between overvalued and undervalued companies that provide dividends. Based on the results of the logistic regression test and the one sample chi-square difference test the proposed hypotheses for the variables can be concluded as follows:

\section{Table 5}

Results of Hypothesis Testing among Variables

\begin{tabular}{lrll}
\hline \multicolumn{1}{c}{ Hypothesis } & Conclusion & Hypothesis & Conclusion \\
\hline Profitability with Dividend Policy & Accepted & Institutional ownership with Dividend & Rejected \\
Introduction stage with Dividend Policy & Accepted & Liquidity with Dividend Policy & Rejected \\
Growth stage with Dividend Policy & Rejected & Dividend Policy with Firm Value & Accepted \\
\hline Mature stage with Dividend Policy & Accepted & & \\
\hline
\end{tabular}

Note: SPSS software data processing.

\section{Discussion}

\subsection{Effect of Profitability on Dividend Policy}

Return on Assets has a positive and significant influence on dividend policy. The higher the profitability of the company, the greater the proportion of dividends. Conversely, the lower the profitability of the company, the less the proportion of dividends. Companies that have profits are, therefore, advised to provide dividends since it will result in the increase of shareholder confidence in the company. This research supports previous research conducted bys Al-Najjar \& Kilincarslan (2017), Hauser \& Thornton (2017), Bulan et al. (2011), Azmal, Negoro \& Syah (2019) and Budiarso (2019) stating that Return on Assets has a positive and significant influence on dividend policy.

\subsection{Effect of Life Cycle Stage of a Company on Dividend Policy}

The companies at their growth stage and mature stage exhibit positive and significant influence on dividend policy. Companies at the stage of growth and maturity have positive operating cash flow, meaning that income derived from the company's 
operational results exists. From this income, the companies would try to provide dividends to investors to show that the company is in good financial and profitable conditions. This research supports previous research presented by Alzoubi (2019) who claimed that companies in their mature stage have a significant proportional relationship on dividend policy. Al-Malkawi (2007) stated that mature companies do not have a great desire to invest in the future, they prefer to instead provide dividends to shareholders. In contrary, new companies at their introduction stage exhibit a positive but non significant effect on dividend policy. This result is similar to a research conducted by Sukkaew (2015) where new stage companies tend not to provide dividends since the profits generated are largely allocated to long-term corporate investments. The results of this study confirm the life-cycle theory which states that companies in the new stage tend not to pay dividends due to future investment opportunities and companies in the growing and mature stages tend to pay dividends to increase shareholder wealth.

\subsection{Effect of Institutional Ownership on Dividend Policy}

Institutional ownership does not affect dividend policy. The insignificance of institutional ownership effect on dividend policy is due to the differences in the desires of institutional investors and individual investors regarding the distribution of dividends. Institutional investors prefer to with hold profits generated for future investment benefits, while individual investors prefer that companies distribute dividends to increase their wealth. This result supports the previous research conducted by Elston et al. ( 2011) and Roy (2015) which show that institutional ownership has no effect on dividend policy.

\subsection{Effect of Liquidity on Dividend Policy}

Liquidity has no effect on dividend policy. The management of a manufacturing company has a short-term liquidity consideration of a company, which is to prioritize the payment of corporate debt to maintain creditor confidence rather than to pay dividends to investors. This trust will be more profitable because the manufacturing industry is an industry that requires large funds to create new products for a very broad market penetration in Indonesia. In contrast to company management, investors prefer dividend payments, that prevents the company liquidity in terms of free cash flow to be too large (El-Nader, 2018). These results support research conducted by Al-Kayed (2017), Rój (2019), Trimawan \& Bertuah (2020) and Sharma (2018) that state liquidity has a negative but non significant effect on dividend policy.

\subsection{Effect of Debt on Dividend Policy}

Debt has a negative and significant effect on dividend policy. The higher the company's debt, the smaller the distribution of dividends to investors. Management is more concerned with debt payments than providing dividends so that large free cash flow can be reduced and occurrence of agency conflict can be avoided. Al-Rahahleh (2017) stated companies with large debts tend not to pay dividends as they need companies need said funds and tend to hold profits rather than pay dividends. The results of this study support research conducted by Ranajee, Pathak \& Saxena (2018), Puspitaningtyas (2019) and Rój (2019) which have proven that corporate debt has a negative and significant effect on dividend policy.

\subsection{Effect of Asset Growth on Dividend Policy}

Asset growth has no effect on dividend policy. The considerations made in companies that experience asset growth to not provide dividends include the fact that the company needs funds to pay debts leading to the with holding of profits. In addition, companies pursue investment opportunities, thus management spends more funds on profitable projects rather than dividends to investors. The lack of influence of asset growth on dividend policy supports previous research by Nguyen, Bui \& Do (2019) and Zainudin, Mahdzan \& Yet (2018).

\subsection{Effect of Investment Cash Flow on Dividend Policy}

Investment cash flow has no effect on dividend policy. The manufacturing industry management policy is more concerned with further investment to continue to add to their business portfolios. This is due to the very high competitiveness in the industry that requires product innovations and broad market expansions to maintain the sustainability of their business. In addition, the amount of cash flow for investments made by management portrays to investors that the management is more concerned with the company's sustainability in increasing market share and company assets so thatit will indirectly provide large profits to investors in the future. Empirical results support the results of research conducted by Sakir \& Fadli (2014), Kighir et al. (2015) and Amar et al. (2017) which stated that cash flow has no effect on dividend policy.

\subsection{Effect of Dividend Policy on Firm Value}

Dividend policy decisions of a manufacturing industry to pay or not pay dividend exhibit different outcomes in the value of the company. Manufacturing companies that provide dividends can increase firm/enterprise value as demonstrated by the value of companies that are overvalued compared to the book value. This means that investors are very interested in investing in manufacturing companies that provide dividends. The results of this study also support the relevance theory put forward by Gordon and Lintner who claimed the policy of providing dividends has a positive effect on the value of the company's shares. 
High dividend distribution will increase the value of the company's shares. These results support previous research conducted by Abor \& Bokpin (2010) and Salih (2010) claiming that dividend policy has a positive and significant impact on firm value.

\section{Conclusion and Limitations of Research}

The study has found a positive and significant influence of the growth and mature stages of a company on dividend policy. A company at its growth starts to provide dividends due to profits created out of its business operations, to signal towards shareholders that the company is worthy of being a place of investment. Companies in their mature stage consistently provide dividends, as opportunities to gain investments tend to decline, to prevent conflicts with agents and maintain investors confidence. Corporate debt also has a significant effect on dividend policy, where companies that have a large debt ratio tend not to provide dividends. This study also shows that dividend policies provide significant difference in the resulting firm value. The present study casts limitation in that only companies in the consumer goods industry sector listed on the Indonesia Stock Exchange from 2014-2018 are sampled amounting to 31 companies. The author suggests a few recommendations for future research. First, object of research can be varied into other industrial sectors accompanied by observations made with longer time period. Second, the research can use other variables related to equity and investment such as return on equity, return on investment and debt to equity which can be linked to dividend policies.

\subsection{Managerial Implications}

This research has attempted to provide perspectives on managerial implications of this study for several parties. For manufacturing companies, it can be used as a consideration to put forth profits obtained for the provisions of dividends to investors as it will increase the value of the company. For investors, this study implies looking at a company's cash flow to know where the company is at inters of its life cycle, in which companies at the stage of growth and maturity tend to provide dividends and companies at its new stage tend not to provide dividends.

\section{Rerefences}

Abor, J., \& Bokpin, G. A. (2010). Investment opportunities, corporate finance, and dividend payout policy: Evidence from emerging markets. Studies in Economics and Finance, 27(3), 180-194.

Ali, I., Gohar, A., \& Meharzi, O. (2017). Why do Firms Change Their Dividend Policy? International Journal of Economics and Financial Issues, 7(3), 411-422.

Al-Kayed, L. T. (2017). Dividend payout policy of Islamic vs conventional banks: case of Saudi Arabia. International Journal of Islamic and Middle Eastern Finance and Management, 10(1), 117-128.

Al-Najjar, B., \& Kilincarslan, E. (2017). Corporate dividend decisions and dividend smoothing: New evidence from an empirical study of Turkish firms. International Journal of Managerial Finance, 13(3), 304-331.

Al-Rahahleh, A. S. (2017). Corporate governance quality, board gender diversity and corporate dividend policy: Evidence from Jordan. Australasian Accounting, Business and Finance Journal, 11(2), 86-104.

Alzoubi, T. (2019). Firms' life cycle stage and cash holding decisions. Academy of Accounting and Financial Studies Journal, 23(1), $1-9$.

Azmal, R., Negoro, D. A., \& Syah, T. Y. R. (2019). The Influence Cash Position Analysis over Debt to Equity Ratio , Return On Assets , And Inventory Turnover on Dividend Payout Ratio : Consumer Goods Companies in Indonesia Stock Exchange 2012-2017 Case Study.

Ben Amar, A., Ben Salah, O., \& Jarboui, A. (2017). Do discretionary accruals affect firms' corporate dividend policy? Evidence from France. Journal of Financial Reporting and Accounting, 16(2), 333-347.

Bertuah, E., \& Ghani, E. K. (2018). Bulls and Bears and Bankruptcy- An Early Warning of Distress. The Journal of Social Sciences Research, (Special Issue 5), 962-969.

Bhattacharya, N., Black, E. L., Christensen, T. E., \& Mergenthaler, R. D. (2004). Empirical evidence on recent trends in pro forma reporting. Accounting Horizons, 18(1), 27-43.

Bradshaw, M. T., Drake, M. S., Myers, J. N., \& Myers, L. A. (2012). A re-examination of analysts' superiority over time-series forecasts of annual earnings. Review of Accounting Studies, 17(4), 944-968.

Brahmaiah, B., Srinivasan, P., \& Sangeetha. (2018). Determinants of Corporate Dividend Policy in India: A Dynamic Panel Data Analysis. Academy of Accounting and Financial Studies Journal, 22(2), 1-13.

Brook, Y., Charlton, W. T., \& Hendershott, R. J. (1998). Do Firms Use Dividends to Signal Large Future Cash Flow Increases? Financial Management, 27(3), 46.

Budiarso, N. S. (2019). Agent, Steward, and Dividend Policy. XXII(3), 83-94.

Bulan, L. T., Subramanian, N., \& Tanlu, L. D. (2011). On the Timing of Dividend Initiations. SSRN Electronic Journal.

Desai, H., Hogan, C. E., \& Wilkins, M. S. (2006). The reputational penalty for aggressive accounting: Earnings restatements and management turnover. Accounting Review, 81(1), 83-112.

Dickinson, V. (2011). Cash flow patterns as a proxy for firm life cycle. Accounting Review, 86(6), 1969-1994.

Elim, J. (2019). Model of Firm Value - Indonesian Stock Exchange Case. International Journal of Economics and Financial Issues, $9(3), 154-162$.

El-Nader, G. (2018). Does stock ownership impact liquidity and dividends? Investment Management and Financial Innovations, 15(3), $111-121$. 
Faccio, M., Lang, L. H. P., \& Young, L. (2001). Dividends and expropriation. American Economic Review, 91(1), 54-78.

Fama, E. F., \& French, K. R. (2001). Disappearing dividends: Changing firm characteristics or lower propensity to pay? Journal of Financial Economics, 60(1), 3-43.

Hakeem, S. A., \& Bambale, A. J. (2016). Mediating Effect of Liquidity on Firm Performance and Dividend Payout of Listed Manufacturing Companies in Nigeria. Journal of Chemical Information and Modeling, 53(9), 1689-1699.

Hauser, R., \& Thornton, J. H. (2017). Dividend policy and corporate valuation. Managerial Finance, 43(6), 663-678. https://doi.org/10.1108/MF-05-2015-0157.

Hofler, R., Elston, J., \& Lee, J. (2011). Dividend policy and institutional ownership: empirical evidence using a propensity score matching estimator. Journal of Accounting and Finance, 11(1), 89 - .

Hosmer, D. W., \& Lemeshow, S. (2000). Applied Logistic Regression. Journal of Environmental Health, Vol. 70.

Husna, A., \& Satria, I. (2019). Effects of Return on Asset, Debt To Asset Ratio, Current Ratio, Firm Size, and Dividend Payout Ratio on Firm Value. International Journal of Economics and Financial Issues, 9(5), 50-54.

Jensen, M. C. (1986). Agency costs of free cash flow, corporate finance, and takeovers. Corporate Bankruptcy, 76(2), 11-16.

Khalid, S., \& Mobeen Ur Rehman. (2015). Determination of Factors Effecting the Dividend Policy of Organizations. International Journal of Information Business and Management, 7(3), 319-334.

Kighir, A. E., Omar, N. H., \& Mohamed, N. (2015). Corporate cash flow and dividends smoothing: a panel data analysis at Bursa Malaysia. Journal of Financial Reporting and Accounting, 13(1), 2-19.

Kilinçarslan, E. (2018). The factors determining dividend policy of financial firms listed on the Borsa Istanbul. Bogazici Journal, $32(1), 1-32$.

Mili, M., Sahut, J. M., \& Teulon, F. (2017). Do corporate governance and ownership structure impact dividend policy in emerging market during financial crisis? Journal of Applied Accounting Research, 18(3), 274-297.

Miller, M. H., \& Modigliani, F. (1961). Dividend Policy, Growth, and the Valuation of Shares. Revue Des Maladies Respiratoires Actualites, 2(4), 326-329.

Nguyen, D. T., Bui, M. H., \& Do, D. H. (2019). The relationship of dividend policy and share price volatility: A case in Vietnam. Annals of Economics and Finance, 20(1), 123-136.

Nizar Al-Malkawi, H. (2007). Determinants of Corporate Dividend Policy in Jordan: An Application of the Tobit Model. Journal of Economic and Administrative Sciences, 23(2), 44-70.

Puspitaningtyas, Z. (2019). Assessment of financial performance and the effect on dividend policy of the banking companies listed on the Indonesia Stock Exchange. Banks and Bank Systems, 14(2), 24-39.

Rahmawati, A., Moeljadi, Djumahir, \& Sumiati. (2018). The effects of managerial ownership, leverage, dividend policy in minimizing agency problem. Investment Management and Financial Innovations, 15(4), 273-282.

Ranajee, R., Pathak, R., \& Saxena, A. (2018). To pay or not to pay: what matters the most for dividend payments? International Journal of Managerial Finance, 14(2), 230-244.

Rój, J. (2019). The Determinants of Corporate Dividend Policy in Poland. The Lahore Journal of Economics, 20(2), 77-98.

Roy, A. (2015). Dividend policy, ownership structure and corporate governance: an empirical analysis of Indian firms. Indian Journal of Corporate Governance, 8(1), 1-33.

Rozeff, M. S. (1982). Growth, Beta and Agency Costs As Determinants of Dividend Payout Ratios. Journal of Financial Research, 5 , 249-259.

Sakir, A., \& Fadli, M. (2014). Influence of managerial ownership, debt policy, profitability, firm size, and free cash flow on dividend policy. Delhi Business Review, 15(1), 15-22.

Salih, A. (2010). The Effect of Dividend Policy on Market Value UK Empirical Study. Doctoral. Unpublished Ph. D Thesis, 295.

Sharma, K. (2018). Impact of dividend policy on the value of Indian banks. SCMS Journal of Indian Management, 15(3), 14-19.

Shubiri, F. N. A.-, Taleb, G. AL, \& Zoued, A. A. - N. A.-. (2012). The Relationship between Ownership Structure and Dividend Policy: An Application in Vietnam Stock Exchange. Academic Journal of Interdisciplinary Studies, 8(2), $131-146$.

Sri Utami, E., \& Ary Gumanti, T. (2019). Analysis of cash dividend policy in Indonesia stock exchange. Investment Management and Financial Innovations, 16(3), 97-105.

Sukkaew, D. (2015). Agency Costs and Free Cash Flow Hypothesis of Dividend Payout Policy in Thailand. Review of Integrative Business and Economics Research, 4(2), 315-328.

Trimawan, E., \& Bertuah, E. (2020). Return on equity as the leading indicator of dividend payout ratio of Jakarta Islamic Index stocks listed on the Indonesia Stock Exchange. Dinasti International Journal of Management Science, 1(3), 319-330.

Vaidean, V. L., \& Moza, C. Z. (2010). The Determinants of Dividend Policy. Indian Institute of Management Calcutta, 37(2), 63-77.

Zainudin, R., Mahdzan, N. S., \& Yet, C. H. (2018). Dividend policy and stock price volatility of industrial products firms in Malaysia. International Journal of Emerging Markets, 13(1), 203-217.

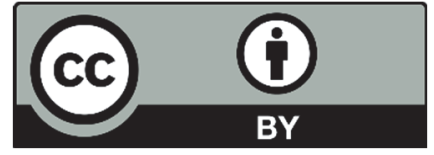

(C) 2020 by the authors; licensee Growing Science, Canada. This is an open access article distributed under the terms and conditions of the Creative Commons Attribution (CC-BY) license (http://creativecommons.org/licenses/by/4.0/). 